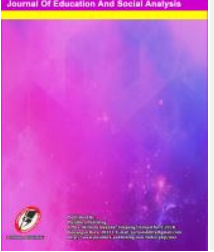

Journal Ability : : Journal of Education and Social Analysis Volume 2, Issue 4, Oktober 2021

\title{
Peran Aqidah Dalam Konflik Antar Umat Beragama Di Kelurahan Tanjung Balai Kota I
}

Fitri Tanjung1, Mardhiah Abbas², Muhammad Nuh Siregar ${ }^{3}$

1,2,3 Universitas Islam Negeri Sumatera Utara

Corresponding Author: @faridasurifada@gmail.com

\begin{tabular}{ll}
\hline & \multicolumn{1}{c}{ ABSTRACT } \\
\cline { 2 - 3 } & Islam adalah suatu agama yang mengajarkan kebenaran- kebenaran dan \\
tata nilai yang universal dan kekal. Akidah secara umum adalah \\
kepercayaan, keimanan, keyakinan, secara mendalam dan benar lalu \\
merealisasikannya dalam perbuatan nya. Sedangkan aqidah dalam agama \\
islam berarti percaya sepenuhnya kepada keesaan Allah, dimana Allah- \\
lah pemegang kekuasaan tertinggi dan pengatur atas segala apa yang di \\
jagad raya. Aqidah ibaratkan sebagai bangunan sehingga aqidah harus \\
dirancang dan dibangun terlebih dahulu dibanding bagian- bagian lain \\
aqidah pun harus dibangun dengan kuat dan kokoh agar tidak mudah \\
goyah yang akan menyebabkan bangunan menjadi runtuh bangunan \\
yang dimaksud disini adalah islam yang benar, menyeluruh dan \\
sempurna aqidah merupakan misi yang ditugaskan Allah untuk semua \\
Rasul- nya, dari pertama sampai dengan yang terakhir, aqidah tidak \\
dapat berubah karena penggantian nama, tempat, atau karena perbedaan \\
pendapat suatu golongan. Kekerasan agama selama berabad- abad \\
merupakan kejahatan terburuk yang telah mengiringi peradaban \\
manusia. Sesuatu yang paradoks karena agama mengajarkan niali- nilai \\
luhur, tetapi agama juga bertanggung jawab terhadap terjadinya \\
kerusakan di muka bumi ini. Akhir- akhir ini kekerasan agama \\
mengalami peningkatan signifikan di indonesia. Indonesia juga memiliki \\
semboyan yaitu bhineka tunggal ika, semboyan ini memiliki makna yang \\
penting karena masyarakat yang hidup di indonesia berasal dari berbagai \\
perbedaan, namun telah hidup dengan rukun dan damai jika masyarakat \\
indonesia selalu mengingat dan berpegang teguh pada semboyan \\
tersebut, maka tidak mudah muncul konflik dalam kehidupan sehari- \\
hari. Pada realita nya negara indonesia negara indonesia nya belom \\
sepenuhnya terbebas dari adanya kekerasan serta konflik hak tersebut \\
banyak dijumpai di negara kita ini.
\end{tabular}

\section{PENDAHULUAN}

Aqidah sebagai pola keyakinan yang berintikan ajaran mengesakan Allah sudah di maklumi semua umat islam sebagai pokok dalam islam ayat- ayat alquran diturunkan di makkah ada tambahan pada ajaran tauhid atau aqidah. 
Ability : Journal of Education and Social Analysis

Volume 2, Issue 4, Oktober 2021

Page : 52-62

Nabi muhammad sendiri telah mencontohkan ajaran yang terkandung dalam alquran. Ajaran agama merupakan lengkap yang digunakan sebagai pedoman hidup untuk mencapai tujuan hidup manusia. Persoalan yang paling pokok dan mendasar dalam beragama adalah aqidah yang berintikan pada keimanan, keimanan merupakan aqidah dan pokok yang diatas nya berdiri syariat islam di aqidah islam adalah kepercayaan- kepercayaan atau keyakinan- keyakinan yang bersyariat islam (Kutsiyyah, 2019).

Aksi kekerasan bukan hanya berdampak dengan rusak nya moral atau aqidah saja tetapi akan berdampak trauma baik bagi anak-anak maupun orang sekitar di desa tersebut dan akan tidak baik bagi masyarakat lainnya. Sejarah kehidupan umat manusia tidak pernah sunyi dari konflik, mulai dari konflik suku sampai kepada konflik agama. Dengan berbagai keanekaragaman yang dimiliki indonesia menjadi hal yang sangat menarik untuk selalu kita teliti dalam segala hal entah budaya, politik, keberagaman dan lain sebagainya. Bangsa indonesia merupakan bangsa yang menjemuk atau beragama, dengan banyak etnis, suku, budaya dan adat istiadat.

Ajaran agama telah mengajarkan sikap toleransi saling menghargai satu sama lain karna islam tidak mengajarkan untuk berbuat kekerasan dalam suatu agama islam tidak pernah memaksakan bahwa berbeda agama itu tidak dapat menjalani silaturahmi tetapi islam itu dapat mengedepankan sikap saling menghormati satu sama lain maka islam sangat mengedepankan sikap toleransi sangat berprinsip untuk mempertahankan kehormatan tentang agama nya karna islam beraqidah mulia akhlakul karimah dalam segala hal (Mursyid, 2016). Jadi jelas sikap yang harus dikedepankan oleh masing- masing pemeluk agama yang notabenenya berbeda dalam keyakinan dan simbol- simbol keagamaan yang dianut atau dipercayai nya adalah sikap yang saling menghargai satu sama lain agar tidak ada konflik yang terjadi dalam antar umat beragama. Karena islam memiliki akidah yang sangat kuat serta memiliki sifat toleransi yang tinggi. Jadi jelas sikap yang harus dikedepankan oleh masing- masing pemeluk agama yang notabenenya berbeda dalam keyakinan dan simbol- simbol keagamaan yang dianut atau dipercayai nya adalah sikap yang saling menghargai satu sama lain agar tidak ada konflik yang terjadi dalam antar umat beragama. Karena islam memiliki akidah yang sangat kuat serta memiliki sifat toleransi yang tinggi.

\section{METODE PENELITIAN}

Penelitian yang digunakan dalam penelitian ini merupakan penelitian kualitatif. Penelitian kualitatif. Kualitatif adalah metode penelitian yang berlandaskan pada filsafat positivisme, digunakan untuk meniliti pada kondisi 
Ability : Journal of Education and Social Analysis

Volume 2, Issue 4, Oktober 2021

Page : 52-62

objek yang alamiah, dimana peneliti adalah sebagai instrumen kunci, teknik pengumpulan adata dilakukan secara triangulasi atau gabungan analisis data bersifat induktif atau kualitatif lebih menekankan makna dari pada generasi (Sugiyono, 2017). Menurut Caswell penelitian kualitatif adalah jenis penelitian yang mengeksplorasi dan memahami makna di sejumlah kelompok orang yang berasal dari masalah sosial. Penelitian kualitatif dapat digunakan untuk meneliti tentang kehidupan masyarakat, sejarah, tingkah laku, konsep, fenomena, masalah dan lain- lain (Semiawan, 2010).

Akar bahan pengamatan ini dibagi menjadi dua jenis, yakni sumber data sekunder dan sumber data primer. Sumber data sekunder adalah seperti catatan atau dokumentasi berupa wawancara data sekunder bersifat data yang mendukung keperluan data primer. Sedangkan data primer adalah data yang diproleh dari responden melalui observasi dan hasil wawancara peneliti dengan narasumber.

Tekhnik pengumpulan data, dalam penelitian peneliti menggunakan data yaitu interview atau tanya jawab merupakan observasi, dokumentasi dan wawancara.

\section{HASIL DAN PEMBAHASAN}

\section{Penyebab Konflik Antar Umat Beragama Dikelurahan Tanjung Balai Kota I Penistaan Agama}

Menurut Kepala lingkungan Tanjung Balai Kota I awal mula terjadinya konflik tersebut bermula dari seorang perempuan yang tinggal didaerah Kelurahan Tanjung Balai Kota I beragama non muslim yang mengeluhkan suara azan yang berkumandang di salah satu masjid Al- maksum dijalan karya berdekatan dengan rumah perempuan non muslim tersebut. Salah satu warga tersebut mengumandangkan azan pada saat itu dan seorang wanita non muslim berkomentar tentang keras nya suara azan yang dikumandangkan dari masjid al Maksum.

Awal nya seorang perempuan non muslim ini hendak pergi berbelanja di salah satu kedai didaerah tidak jauh dari rumahnya dia mengatakan kepada si penjaga kedai dia mengatakan bahwa "kak dulu suara masjid kita tidak begitu besar ya, sekarang agak besar ya" dengan nada yang pelan dan tidak ada bahwa sanya perempuan non muslim ini melarang azan dikumandangkan begitulah ujar dari seorang warga yang menjaga kedai tersebut.

Berita pun tersebar luas, salah seorang warga tersebut menyampaikan perkataan dari perempuan non muslim ke pengurus masjid al maksum bahwa perempuan non muslim tersebut melarang azan dikumandangkan. Setelah berita itu disampaikan kepada pengurus masjid ia pun membicarakan tentang 
Ability : Journal of Education and Social Analysis

Volume 2, Issue 4, Oktober 2021

Page : 52-62

hal itu kepada remaja- remaja masjid tersebut atauu pengurus masjid bahwasanya ada seorang umat non muslim berkomentar tentang keras nya suara azan yang di kumandangkan dalam masjid yang mereka sendiri.

Setelah bermusyawarah dengan pengurus masjid mereka tidak begitu mempermasalahkan permasalahan tersebut karena mereka menganggap mungkin hanya ke salah pahaman saja karna mereka menganggap bahwa mungkin berita yang tersebar ditambah- tambahi untuk mempropokasi atau memanas- manasi antar umat beragama. Tetapi di Kelurahan Tanjung Balai Kota I mendapat telepon dari salah satu masyarakat melaporkan atas kejadian bahwa si perempuan non muslim tersebut dianggap menistakan agama dan ada salah satu warga yang tidak terima dan melaporkan si perempuan non muslim tersebut.

Menurut keterangan dari kepala lingkungan Kelurahan Tanjung Balai kota I ketika dimana mereka mendapat telepon dari salah satu masyarakat ketika itu juga kepala lingkungan mendatangkan pihak kompeten atau disebut komas untuk menanyakan atau membicarakan bahwa sanya ada rusuh atau disebut konflik yang mana ada permasalahan yang menyetopkan suara azan yang dimana kepala lingkungan menyelidiki kepihak yang bersangkutan.

Setelah itu kepala lingkungan Kelurahan Kota tanjung Balai Kota I memanggil kepala lurah dimana kepala lurah menyepakati untuk memanggil siperempuan non muslim tersebut ke kantor lurah Tanjung Balai Kota I untuk mediasi dan ternyata masyarakat sudah banyak tau tentang kejadian ini melalui media sosial disitu juga masyarakat berkumpul untuk bersuara agar siperempuan non muslim dibawa ke polsek dan setelah itu dibawa kepolres yang mana dia ditetapkan menjadi tersangka sampai dibawa kepangadilan pada saat itu dan jatuhkan hukuman setahun delapan bulan pada saat itu.

Setelah itu perempuan non muslim itu di bawa ke kantor Kelurahan Tanjung Balai Kota I untuk menjelaskan bagaimana keterangan si perempuan apakah memangg benar adanya bahwasanya dia mengatakan hal tersebut. Setelah mendapat keterangan dan masyarakat pun ikut bersuara untuk si perempuan ini dilaporkan dengan pihak berwewenang karna menurut kepala lingkungan I harus ditindak lanjuti karna tidak ada lagi kata maaf untuk kasus ini karna dianggap sudah melewati batas.

Setelah pulang dari kantor Kelurahan sebelum di bawa kepolsek tiba- tiba terjadi konflik yang mana rumah perempuan muslim hampir dibakar oleh warga tetapi tidak jadi dibakar mereka membakar kelenteng tempat ibadah umat cina mereka melakukan pembakaran lantas mengeluapkan emosi mereka yang sudah menghina agama islam. Tetapi yang membakar kelenteng itu 
Ability : Journal of Education and Social Analysis

Volume 2, Issue 4, Oktober 2021

Page : 52-62

bukan dari masyarakat Kelurahan Kota Tanjung Balai Kota I tetapi dari masyarakat luar yang mana tidak tau dari asal- usul nya.

Pelaku pembakaran tempat ibadah cina ada beberapa pada saat itu dilihat dari keterangan masyarakat Kelurahan Kota Tanjung Balai Kota I bukan dari warga mereka tetapi dari warga luar yang datang bergabung untuk melakukan aksi pemabakaran tempat ibadah mereka bukan hanya satu tempat ibadah cina yang dibakar pada saat itu ternyata ada delapan atau lebih kelenteng ibadah cina yang dibakar oleh masyarakat dari luar.

Mereka meluapkan emosi pada saat itu karna sudah sering sabar dengan orang non muslim di daerah tersebut. Tetapi disini tidak ada korban jiwa ataupun melakukan kekerasan tetapi hanya melakukan aksi pembakaran dan pelaku pembakaran pun sudah di bawak ke polsek dan diamankan pada saat itu dan dijatuhkan hukuman atas tindakan mereka yang melakukan aksi pada saat itu.

Setelah dari kejadian tersebut siperempuan non muslim dibawa kepolsek dan dijatuhkan hukuman setahun delapan bulan karna dianggap melecehkan agama islam di jalan Karya Kelurahan Tanjung Balai Kota I menjalani hukuman atas perbuatan nya dan pada saat itu tidak ada perdamaain nya dan pelaku pembakaran cina pun sudah dijatuhkan hukuman penjara juga karna pelaku tersebut bukan dari kalangan msayarakat yang menghadapi asal mula dari permasalahan tersebut.

Setelah kejadian konflik itu tidak begitu kepanjangan hanya saja dalam beberapa hari masyarakat Kelurahan Tanjung Balai Kota I hidup kembali seperti semula tidak ada lagi perdebatan ataupun pertengkaran mereka hidup seperti biasa. Silaturahmi pun tetap terjaga antara umat beragama yaitu antara muslim dan cina tidak ada lagi kejadian yang tidak saling menghargai satu sama lain. Dan tempat ibadah cina yang dibakar tadi pun sudah di bangun kembali seperti semula.

Karna islam saling memaafkan sesama manusia walaupun berbeda- beda keyakinan umat islam tetap menjaga silaturahmi mereka wkarna islam mengajarkan untuk berbuat baik selalu kepada orang- orang lain.

\section{Pemahaman Aqidah Masyarakat Kelurahan Tanjung Balai Kota I}

Menurut masyarakat Kelurahan Tanjung Balai Kota I berpendapat bahwa aqidah itu adalah perilaku seseorang mencerminkan perilaku kita seperti sopan santun, berbudi bahasa, simpati dan mewujudkan akhlak yang mulia. Aqidah juga merupakan sikap yang baik terhadap apapun baik itu dari segi dari kehidupan kita sendiri maupun berada dilingkungan kita sendiri. Aqidah bukan hanya ada di diri kita sendiri tetapi ada juga dilingkungan kita seperti 
hal nya tadi aqidah dalam menghadapi permasalahan apapun baik didiri kita maupun dilingkungan sekitar kita.

Dalam setiap agama pasti ada aqidah yang dipegang oleh penganut agama contoh nya kita sebagai umat islam sangat berepegag teguh dalam aqidah islam dan aqidah yang benar itu tentu saja hanya ada di ajaran islam jadi jelas bahwa kita sebagai umat islam harus memilki aqidah yang benar terlebih dahulu sehingga kita tidak tidak akan melanggar syariat atau ajaran islam dimana nantinya kita dapat membedakan aqidah mana yang baik dan aqidah mana yang buruk.

Aqidah itu sebagai umat islam agama yang sangat bertoleransi yang saling menghargai satu sama lain karna kita kan sebagai umat islam mempunyai aqidah, kita mengetahui tentang agama islam pasti kita tahu ajaran islam itu dimana kita harus menghindari suatu perdebatan dalam konflik tersebut karna agama itu bertata rapi dan agama yang tenang damai dan rukun.

Aqidah juga merupakan suatu keyakinan kepada yang pencipta atau Allah yang menganjurkan manusia untuk meyakini rukun iman sebagai umat islam yaitu iman kepada Allah, iman kepada malaikat, iman kepada kitabkitab, iman kepada rasul, iman kepada hari kiamat, dan iman kepada hari qadha dan qhadar. Sebagai umat islam kita wajib mempercayai rukun iman tersebut itulah bukti bahwasanya kita meyakini Allah dengan sepenuhnya.

\section{Peran Aqidah Dalam Masyarakat Kelurahan Tanjung Balai Kota I}

Peran aqidah yang dilakukan masyarakat Kelurahan Kota Tanjung Balai Kota I dalam konflik antar umat beragama kami melakukan permusyawarahan terlebih dahulu untuk menangani masalah tersebut mereka tidak melakukan tindakan atau perbuatan yang diluar batasan dan tidak menghakimi atau melakukan kekerasan dengan seorang yang telah dianggap menjadi penistaan agama mereka merundingkan terlebih dahulu kepada pihak yang bersangkutan dan masyarakat nya pun ikut bermusyawarah dalam kantor Kelurahan Tanjung Balai Kota I.

Bermusyawarah dilakukan bukan hanya kepada lurah saja tetapi dilakukan kepala lingkungan untuk bermusyawarahkan kepada polsek dan ketua remaja masjid untuk meminta pendapat bagaimana cara penyelesaian konflik tersebut. Jadi peran yang dilakukan masyarakat dalam konflik tersebut terutama dalam ketua remaja masjid yaitu mereka sudah memaafkan atas kesalahan siperempuan non muslim dan tidak akan diperpanjang urusan nya karna dari awal mereka tidak mempermasalahkan nya karna berita nya sudah 
Ability : Journal of Education and Social Analysis

Volume 2, Issue 4, Oktober 2021

Page : 52-62

tersebar luas kemedia sosial otomatis ada asutan- asuatan dari luar sehingga menyebabkan konflik itu terjadi.

Dalam ajaran islam, aqidah memiliki kedudukan yang sangat penting. Ibarat suatu bangunan, aqidah adalah pondasinya, sedangkan ajaran yang lain, sepertiibadah dan akhlaq adalah sesuatu yang dibangun diatasnya. Untuk itu rumah yang dibangun tanpa pondasi, pastilah sangat rapuh dan biasanya mudah runtuh bahkan tidak diperlukan kekuatan besar untuk merobohkan nya, cukup dengan angin kecil saja, sehingga untuk sekedar bangunan tersebut akan runtuh dan hancur berantakan.

Karna kalau kita beraqidah kita tidak boleh terpancing emosi, kalau kita terpancing emosi nanti yang ada kita melakukan tindakan yang diluar batasan dan pasti akan berantakan disitulah peran aqidah kita karna kita bisa mengkontrol emosi, menahan semua nya sehingga kita tidak melakukan tindakan yang diluar batasan islam dan aqidah ini sangat jelas berperan dalam kehidupan kita sebagai umat islam.

Sebagai sikap seorang muslim terjadi kerusuhan atau konflik antar umat beragama yang merupakan pelecehan agama islam dan mengakibatkan konflik antara islam dan non muslim maka kita sebagai seorang muslim bersikap keras untuk membawa kejalur hukum yang berwajib agar permasalahan selesai dengan tenang dan tidak ada konflik yang mengakibatkan kerusuhan atau kekerasan dalam permasalahan tersebut.

Sedangkan menurut masyarakat lainnya berpendapat tentang peran Aqidah dalam konflik tersebut, yaitu bertanggung jawab sebagai umat islam untuk membela agama islam kita sendiri tetapi sebelumnya kita harus mengetahui apa permasalahan sebenarnya apabila memang dari agama kita yang bersalah maka ikut mempermasalahkan agama kita begitu juga sebalik nya apabila umat non muslim bersalah dalam konflik ini masayarakat islam dikelurahan kota tanjung balai kota I akan bertindak dalam membela agama islam.

Tindakan yang dilakukan oleh masyarakat Kelurahan Kota Tanjung Balai I ia berpendapat bahwa dia membenarkan tindakan tersebut dalam membela agama islam. Memang benar islam itu mengemukakan toleransi dalam agama islam tetapi non muslim tidak melakukan tersebut mereka semena- mena dalam agama islam bahkan mereka berulang kali dalam melecehkan islam tersebut dan tidak bisa diam lagi sebagai umat islam maka dari itu sebagian dari masyarakat kelurahan Tanjung Balai kota I melakukan aksi tersebut tetapi tidak melakukan kekerasan dalam sipelaku tersebut.

Karna sudah tertera di dalam hadist yang artinya "untuk mu agama mu dan untuk ku agama ku" jadi jelas disini dikatakan bahwa sikap toleransi itu 
Ability : Journal of Education and Social Analysis

Volume 2, Issue 4, Oktober 2021

Page : 52-62

ada yaitu saling menghargai. Jadi menurut masyarakat Tanjung Balai Kota I apapun itu dia membela agama nya dalam keadaan apapun. Ibarat rumah kita di usik atau dilempar orang kita marah apalagi agama kita diusik jadi perbuatan itu adalah suatu pelajaran supaya umat non muslim tidak melakukan hal yang sama kedepan nya nantinya.

Bersikap bijak dalam bertindak jangan sampai kita mudah percaya kepada orang non muslim yang bisa merusak kepercayaan atau keyakinan kita untuk mengikuti ajaran mereka sebab kita bisa saja terpengaruh walaupun kita sudah mempunyai aqidah yang kuat dan mantap bisa saja kita terpengaruh karna kita bukan nabi kita manusia biasa oleh karena itu berhati- hati lah dalam msuatu hal dan alangkah baik nya kita memutuskan hubungan perdangangan atau bisnis yang terjalin pada mereka.

\section{Pengaruh Aqidah Masyarakat Dalam Konflik Antar Umat Beragama Di Kelurahan Tanjung Balai Kota I}

Terjadinya konflik suatu wilayah pasti ada pengaruh nya di dalam masyarakat dalam menghadapi konflik tersebut. Seperti salah satunya terjadi di kelurahan Tnjung Balai Kota I sangat berpengaruh kepada masyarakat nya yaitu perubahan kenyamanan atau keharmonisan di daerah itu dampak nya sangat berpengaruh sekali pada masyarakat nya seperti itu tadi perubahan di desa tersebut tidak lagi harmonis karna masyarakat antar umat beragama tidak lagi saling menghargai satu sama lain dan menghapuskan sikap toleransi.

Menurut keterangan masyarakat di dalam konflik pada waktu itu putusnya silaturahmi sangat mempengaruhi aqidah masyarakat karena timbul nya kebencian antara masyarakat kelurahan Tanjung Balai kota I dengan antar umat etnis yaitu umat cina. Dalam masyarakat terjalinnya silaturahmi yang pada awal nya sangat menjaga agar tetap selalu terjaga dan itu merupakan pegangan umat Islam dikelurahan Tanjung Balai kota Silaturahmi harus dilakukan untuk seluruh umat islam, baik yang ada kaitan nya maupun tidak ada ikatannya seperti hal nya dengan umat non muslim atau berbeda keyakinan kita tetap menjaga silaturahmi kita harus berbuat baik dengan saling menghormati dan menghargai hanya saja bentu etika nya yang berbeda.

Sifat kasih sayang dengan umat manusia ini sangat penting karena ketika sudah tidak ada lagi kasih sayang maka yang terjadi adalah pertengkaran dan permusuhan bahkan juga bisa menimbulkan dampak negatif.

Oleh karena itu sifat silaturahmi baik yang bersifat khusus maupun bersifat umum ini sangat diperlukan demi tercapai nya kedamaiaan kerukunan dan persatuan umat manusia di muka bumi ini. Makna silaturahmi sangat universal akan tetapi intinya satu yaitu berbuat baik, sedangkan teknik, 
Ability : Journal of Education and Social Analysis

Volume 2, Issue 4, Oktober 2021

Page : 52-62

metode, sarana dan prasarana silaturahmi dapat dikembangkan sesuai dengan perkembangan zaman dan tempat karena implikasi dari silaturahmi yang kerabat, sesama muslim, tanpa membedakan keturunan ras, agama dan bangsa.

Dalam sebuah hadist dinyatakan bahwa silaturahmi merupakan salah satu cara untuk mendekati surga dan menjauhi neraka tidak ada kebaikan yang lebih cepat mendapat pahala selain silaturahmi dan tidak ada kebaikan yang kebih cepat mendatangkan azab Allah untuk memutuskan silaturahmi.

Namun adanya konflik terjadi berpengaruhi putusnya tali silaturahm aqidah masyarakat Kelurahan Kota Tanjung Balai Kota I tapi tidak semua pertalian silaturahmi terputus dalam konflik itu hanya sebagian yang terlibat dalam konflik tersebut. Padahal kita tahu memutuskan tali silaturahmi itu tidak dibolehkan dalam ajaran islam bahkan akan berdampak buruk yang memutuskan silaturahmi. Dari keterangan masyarakat Kelurahan Tanjung Balai Kota I terputusnya silaturahmi pada dalam waktu konflik itu saja dan konflik itu tidak berkepanjangan hanya saja dalam beberapa hari masyarakat Kelurahan Tanjung Balai Kota I kembali seperti semula dalam membina silaturahmi dan saling menghargai satu sama lain.

Terganggu nya ibadah sangat mempengaruhi aqidah masyarakat kelurahan Tanjung Balai Kota I seperti melakukan sholat lima waktu. Sholat sangat diwajibkan untuk umat islam itu adalah salah satu perintah dari Allah swt dan merupakan bentuk keyakinan kita terhadap Allah swt. terganggu nya ibadah sama hal nya sholat nya tidak khusyuk dalam melakukan sholat seperti mana kita tahu sholat itu harus sepenuhnya kepada Allah.

Tetapi karna adanya konflik di sekitar kita pasti timbul rasa kekhawatiran dalam diri kita karna kita tahu konflik bisa saja terjadi kapan saja kita tidak tahu bisa saja masyarakat non muslim membalas atau melakukan penyerangan pada umat islam jadi ini sangat mempengaruhi aqidah masyarakat.misalnya sholat jemaah ke masjid di tengah sholat bisa saja bisa saja konflik itu terjadi lagi otomatis pikiran menjadi ragu dan was- was.

Timbul nya rasa ketakutan dalam diri mereka ini juga sangat berpengaruh sekali dalam aqidah masyarakat Kelurahan Tanjung Balai Kota I pada saat itu karna muncul nya rasa takut dan tidak aman. Seperti kita ketahui di dalam konflik tersebut pasti situasi yang tidak kondusif, kerusuhan, bentrokan dan kekerasan pasti sangat berpengaruh pada masyarakat yang tinggal di Kelurahan Tanjung Balai Kota I.

Mereka takut akan terjadi kepada mereka dan akan terjadi terulang lagi dan mereka berpikir bahwa non muslim akan melakukan hal yang sama dengan membakar masjid tempat beribadah islam disini pengaruh aqidah mereka goyah karna ketakutan mereka pada kaum non muslim takut akan 
Ability : Journal of Education and Social Analysis

Volume 2, Issue 4, Oktober 2021

Page : 52-62

adanya konflik lagi karna konflik nya bukan hanya masyarakat dikelurahan tanjung balai kota I saja tetapi dari luar yang belum diketahui asalnya dari mana.

\section{KESIMPULAN}

Adapun kesimpulan dari pengamatan ini adalah Dalam kehidupan masyarakat di wilayah hal- hal yang berkaitan dengan hubungan antar umat beragama masih dianggap tabu sehingga munculah berbagai reaksi yang mengarah pada tindakan diskriminasi. Dikelurahan tanjung balai Kota I berpaham bahwa aqidah mereka masih belum luas atau belum menerapkan peranan aqidah dalam diri mereka.

Masyarakat masih belum memahami aqidah yang benar mereka masih mengetahui aqidah secara umum saja tetapi tidak memahami aqidah sebenarnya maka dari itu perlu kita tingkatkan aqidah kita agar tidak terjadi lagi konflik terhadap masyarakat antara umat beragama sehingga kita sebagai umat islam tidak terpengaruh pada aqidah kita tapi berpengaruh dalam positif sehingga aqidah kita tetap terjaga dengan baik. Untuk mencapai tujuan terciptanya hubungan antar umat beragama sikap toleransi harus juga kita terapkan agar menjadi rukun dan damai dan menjauhkan dari sikap keras dan mengandalkan ego masing- masing dan harus menerapkan pemahaman tentang aqidah dan mendalami ajaran agama yang benar.

Beberapa dalam pengamatan ini adapun saran yaitu Untuk lebih memahami lagi aqidah yang baik bukan hanya untuk masyarakat kelurahan Tanjung Balai Kota I tetapi untuk semua umat muslim agar terciptanya aqidah yang benar dan dijauhkan dari aqidah yang bathil agar terwujudnya aqidah islamiyah antara umat muslim. Dan penelitian ini merupakan keterbatasan waktu untuk dalam proses mengerjakannya saya berharap bahwa adanya konflik ini dapat menjadi pelajaran buat kita agar bisa kedepan nya menciptakan aqidah islamiyah yang benar.

\section{REFERENCES}

Kutsiyyah, 2019 Pembelajaran Akidah Akhlak, (CV Duta Media,)

Salma Mursyid, Journal Of Islamand Plurality, Volume 2,

Sugiyono, 2017 Metode Penelitian Kualitatif, Kuantitatif, Dan RED, (Bandung: Alfabeta.)

Conny R, Semiawan. 2010 Metode Penelitian Kualitatif. (Jakarta : Grasindo),

Departemen Pendidikan Nasional, 2014. Kamus Bahasa Indonesia, (Jakarta: Pt Gramedia Pustaka Utama)

Arni Muhammad,2009 Komunikasi Organisasi, (Jakarta:PT. Bumi Aksara,), 
Ability : Journal of Education and Social Analysis

Volume 2, Issue 4, Oktober 2021

Page : 52-62

Rosihon Anwar, 2008 Aqidah Akhlak, (Bandung: Pustaka Setia,).

Masan AF. 2014 Pendidikan Agama Islam Akidah Akhlak Madrasah Tsanawiyah, Semarang:PT. Karya Toba Putra).

Asroruddin Al Jumhuri, 2019 Belajar Aqidah Akhlak, (Yogyakarta: PENERBITAN DEEPUBLISH (Grup Penerbit CV BUDI UTA)

Al-Imam Jalaluddin Muhammad bin Ahmad bin Muhammad Al-Mahalli Dkk. 2015 Tafsir Jalalain Jilid 1, (Surabaya: PT. elBA Fitra Mandiri Sejahtera),.

Anwar Rosihon, Saehudin, .2016 Akidah Akhlak, (Bandung: CV Pustaka Setia,) . Rosihon Anwar, Saehudin,2016 Akidah Akhlak, (Bandung: CV Pustaka Setia)

Firdaus M Yunus, Konflik Agama Di Indonesia, Subtansia. 